interest of some private gentlemen and to some professors of modern botany who "spend their whole leisure from their professional duties in the arduous labour of palæobotanical research."

But "there is no professorship of palæobotany at any of our universities or colleges. There is no lectureship or readership in palæobotany at any of our universities or colleges; and Cambridge alone has a demonstratorship, which is so ill-paid that it might be thought libellous to state the official salary attached. There is no post of palæobotanist to our Survey. . . There is no post of palæobotanist at our great national Natural History Museum."

After having shown what has been done for palæobotany at Berlin, Stockholm, and Washington (U.S. Geological Survey), and after having developed the reasons--scientific and economic-why palæobotany should receive official support in Britain also, the author asks: "What should be done?" and supplies the following answer:--

"Much in the future. For the present what is urgently needed are professorships and lectureships at one or two of the universities-a professorship, for instance, in London, which would reach the geological students who go out from the School of Mines to all parts of the world. Then two posts at least should be established at the British Museum of Natural History: one for a palæobotanist of standing and repute who has travelled, who with a wide knowledge of the subject could fitly represent the science, and who, keeping abreast of the subject, could direct the work of a junior, and ultimately of several juniors. In our museum at present there are many specialists on animal fossils, and an important department of animal palæontology, while the palæobotanical department does not exist, and though there is a valuable collection of fossil plants the authorities only get in outside specialists from time to time to write monographs on them.

"What is ultimately wanted for the science is a properly equipped institute of palæobotany, which should represent all its sides - with a well-arranged museum, an academic and also economic side to its activities. The immediate need for the foundation of some posts in palæobotany should give trustees and governors food for thought, and might give some millionaire, anxious to be of service to his day and generation, an opportunity to do a unique and serviceable deed in endowing this neglected but important science."

The same appeal for the recognition of palæobotany as in the article referred to has recently been taken up again by Dr. Marie C. Stopes, in a lecture delivered at University College (University of London), on October 17 , and published in an abridged form in NATURE of November 20, I9I3. To the question what the palæobotanist in the future will demand the following answer is given :- "That in at least one institution in each civilised country there shall be a recognition of his science and adequate accommodation for it," after which the plan and details for such an institution, according to the opinion of Dr. Stopes, are fully developed for which the number of this journal cited should be consulted.

It is earnestly to be hoped that this proposition will be realised, and at the same time realised in the right way. As keeper of the palæobotanical department of the State Museum of Natural History (Naturhistoriska Riksmuseum) at Stockholm, which was specially mentioned in the article referred to, I may be permitted to express my opinion regarding the proposed palæobotanical institution. I have, it is true, no idea of the present position of the question here discussed, nor if there is any possibility of the realisation of the plan proposed below. But I hope that my British fellow-workers will not consider my suggestion as an intrusion, since they are probably aware of my deep interest in British palæobotany, by which I have profited so much myself during repeated visits to Britain.

I quite agree with Dr. Stopes that the establishment of a properly equipped British institute of palæobotany is a most urgent need, which ought not to be postponed. But in order to give such an institute an opportunity for working under the best conditions possible, I consider it almost necessary that it should b. established in connection with the Royal Botanic Gardens, Kew. The reason for such a connection is simply this: that the scientific study of palæobotany signifies a constant and repeated comparison of the fossil plants with the recent ones. For the botanical determination of Palæozoic and Mesozoic plants the palæobotanist must compare the recent Pteridophytes and Gymnosperms, especially the tropical ones; and there exists no better opportunity than in the Kew Gardens, where the hothouses, temperate houses, museums, and herbaria offer the most excellent and complete materials possible for such work. The same holds true for the determination of dicotyledonous leaves of the Cretaceous and Tertiary. The determination of those leaves is a most difficult task, for which an extensive and repeated comparison with the leaves of trees and shrubs of the arboretums and gardens, of the temperate houses and hothouses, and, ultimately, of the herbaria is necessary. There is no other place in the United Kingdom which offers such excellent opportunities for this work as the Kew Gardens; and the same holds true for the determination of leaves, fruits, and seeds from the Quaternary also. It therefore seems evident that the Kew Gardens are the right place for the establishment of a palæobotanical institute, the headquarters for the British palæobotany of the future.

Stockholm, December 12, 1913.

\section{Electrodeless Spectra of Hydrogen.}

WHILE making experiments on the apparent production of neon and helium during electric discharges, I have noticed an effect which may be of interest to spectroscopists. A powerful oscillatory discharge is produced in eight or nine coils of wire from two Leyden jars, with a spark-gap of about 2 in. in parallel, connected to a large coi! which is run from the main supply. Set in the coils of wire is a glass bulb of about 300 c.c. capacity provided below with a small bulb containing cocoanut charcoal, and connected by a side-tube and tap with a mercury pump. After evacuating, heating, and "washing out," the bulb with hydrogen, when pure hydrogen is admitted at a fairly low pressure and the discharge is passed, the glow is bluish in colour, and shows both hydrogen and mercury spectra; but if the charcoal bulb be cooled in liquid air so that mercury vapour and any other impurities are completely removed, the glow is of a brilliant rose colour, and shows only hydrogen lines. If the pressure is reduced, however, to a value somewhere below I mm., there appears in the middle of the rose ring a fairly bright blue zone; and whereas the former shows both the simple and complex spectra of hydrogen, the blue zone shows nothing but the elementary line spectrum; and, moreover, the blue line $\lambda_{4} 86 \mathrm{I}$ is more intense than the red line. Further reduction of pressure causes the obliteration of the blue zone by the spreading inwards of the rose ring.

As I have not found any mention of this isolation of the primary spectrum, with weakening of the $a$ line, in pure dry hydrogen, the fact is possibly worth recording. IRVINE MASSON.

University College, London, December I I. NO. 23O5, VOL. 92] 